\title{
Effect of sugarcane treated with non-protein nitrogen and hydrolyzed with calcium oxide in the diet of dairy steers
}

\section{Efeito da cana-de-açúcar tratada com nitrogênio não proteico e hidrolisada com óxido de cálcio na dieta de novilhos leiteiros}

\author{
Baltazar Alves da Silva Junior ${ }^{1 *}$; Marcus Vinicius Morais de Oliveira²; Paulo \\ Maltempi Filho3 ${ }^{3}$; Dirce Ferreira Luz ${ }^{4}$; Rafael Henrique de Tonissi e Buschinelli \\ Goes $^{5}$; Fernando Miranda de Vargas Junior ${ }^{5}$
}

Highlights:

Hydrolysis with quicklime and urea inclusion in sugarcane an increase in intake.

$1.0 \%$ quicklime does not change the digestibility of fibrous fraction of sugarcane.

Hydrolyzed sugarcane associated the urea increases serum calcium and nitrogen levels.

\begin{abstract}
This study examines the effect of sugarcane hydrolyzed with calcium oxide (quicklime) associated with non-protein nitrogen (a mixture of urea and ammonium sulfate) on nutrient intake, rumen degradability and kinetics, intestinal digestibility and blood and urinary parameters in dairy steers. The treatments consisted of fresh sugarcane $(\mathrm{Sc})$; fresh sugarcane with urea $(\mathrm{ScUr})$; sugarcane hydrolyzed with quicklime $(\mathrm{ScQl})$; and sugarcane hydrolyzed with quicklime plus urea (ScUrQl), maintaining a roughage:concentrate ratio (DM basis) of 70:30. Four rumen-cannulated Jersey steers were used in a Latin square design for data collection. The animals were fed the respective diets for 72 days. Mineral matter intake differed across the treatments, with higher values obtained with the treatments containing quicklime. The average mineral matter intake was $0.27,0.22,0.54$ and $0.48 \mathrm{~kg} \mathrm{day}^{-1}$ for the Sc, ScUr, ScQ1 and ScUrQ1 treatments, respectively. Short-chain fatty acid and ammoniacal nitrogen concentrations, $\mathrm{pH}$, rumen-fluid kinetics and potential degradability of DM ("a" + "b" fractions) were not influenced by the additives. The diets containing quicklime provided an increase in calcium absorption, which averaged 18.7, 21.3, 25.8 and $26.5 \%$ for the Sc, ScUr, ScQ1 and ScUrQl treatments, respectively. Serum nitrogen levels were higher in the animals fed urea, averaging 12.3, 20.4, 15.3 and $21.1 \mathrm{mg} \mathrm{dL}^{-1}$ urea for the Sc, ScUr, ScQl and $\mathrm{ScUrQ1}$ treatments. However, urinary glucose and nitrogen excretion levels did not differ significantly. Hydrolysis with quicklime and the inclusion of urea in sugarcane promote increases in intake, absorbed calcium and plasma nitrogen levels.
\end{abstract}

Key words: Degradability. Quicklime. Rumen kinetics.

\footnotetext{
1 Discente do Curso de Mestrado do Programa de Pós-Graduação em Zootecnia, Universidade Federal da Grande Dourados, UFGD, Dourados, MS, Brasil. E-mail: bjr_vet@hotmail.com

2 Prof. Dr., Universidade Estadual de Mato Grosso do Sul, UEMS, Aquidauana, MS, Brasil. E-mail: marcusvmo@yahoo.com.br

3 Discente do Curso de Mestrado do Programa de Pós-Graduação em Zootecnia, UEMS, Aquidauana, MS, Brasil. E-mail: paulo_ mal@hotmail.com

4 Prof $^{\mathrm{a}}$ Dr $^{\mathrm{a}}$, Universidade Federal de Mato Grosso do Sul, UFMS, Aquidauana, MS, Brasil. E-mail: dirceluz@yahoo.com.br

5 Profs. Drs., UFGD, Dourados, MS, Brasil. E-mail: rafaelgoes@ufgd.edu.br, fernandojunior@ufgd.edu.br

* Author for correspondence
} 


\section{Resumo}

Objetivou-se avaliar o efeito da cana-de-açúcar hidrolisada com óxido de cálcio (cal virgem) associado à nitrogênio não proteico (mistura de ureia com sulfato de amônio) sobre o consumo de nutrientes, degradabilidade e cinética ruminal, digestibilidade intestinal e os parâmetros sanguíneo e urinário em novilhos leiteiros. Os tratamentos testados foram a cana in natura $(\mathrm{Ca})$; cana in natura com ureia $(\mathrm{CaUr})$; cana hidrolisada com cal virgem $(\mathrm{CaCal}) \mathrm{e}$ cana hidrolisada com cal virgem mais ureia (CaUrCal), mantendo-se em todas as dietas uma relação volumoso:concentrado, na matéria seca, de 70:30, respectivamente. Quatro novilhos Jersey, canulados ruminalmente, foram utilizados num delineamento em quadrado latino para a coleta dos dados, sendo os animais alimentados durante 72 dias com as respectivas dietas. Houve diferença no consumo de matéria mineral, sendo maior nos tratamentos contendo cal virgem, com médias de 0,27, 0,22, 0,54 e 0,48 $\mathrm{kg} \mathrm{dia}^{-1}$ para os tratamentos $\mathrm{Ca}, \mathrm{CaUr}, \mathrm{CaCal}$ e CaUrCal, respectivamente. As concentrações de ácidos graxos de cadeia curta (AGCC) e nitrogênio amoniacal $\left(\mathrm{N}_{-} \mathrm{NH}_{3}\right), \mathrm{o} \mathrm{pH}$, a cinética da fase líquida ruminal, e a degradabilidade potencial (frações " "a" + "b") da MS não foram influenciadas pelos aditivos. As dietas contendo cal virgem proporcionaram uma maior absorção de cálcio, com médias de 18,7, 21,3, 25,8 e 26,5 \% para os tratamentos $\mathrm{Ca}, \mathrm{CaUr}, \mathrm{CaCal}$ e $\mathrm{CaUrCal}$, respectivamente. Os níveis de nitrogênio sérico dos animais alimentados com ureia foram superiores, com média de 12,3, 20,4, 15,3 e 21,1 mg de ureia $\mathrm{dL}^{-1}$ para os tratamentos $\mathrm{Ca}, \mathrm{CaUr}$, CaCal e CaUrCal; porém, os níveis de glicose e as excreções de nitrogênio na urina foram semelhantes. A hidrolise com cal virgem e a inclusão da ureia na cana-de-açúcar promovem aumentos nos consumos e nos níveis de cálcio absorvido e de nitrogênio plasmático.

Palavras-chave: Cal virgem. Cinética ruminal. Degradabilidade.

\section{Introduction}

Amongst grasses used as roughage in tropical environments during the dry season, sugarcane stands out with high biomass production potential per area and the ability to provide large amounts of soluble carbohydrates to the diet of ruminants. As such, this crop has the lowest cost per ton of dry matter (DM) and energy (Mota et al., 2010), in addition to being easily cultivated and adapting to different soils and climates.

However, sugarcane has low levels of crude protein, which do not exceed $4 \%$, and is highly deficient in minerals, especially phosphorus and sulfur (Oliveira et al., 2007). The greatest limitation to its use is nonetheless the low degradation of its fiber in the rumen, which induces a reduction of passage rate. As a result, non-degraded components accumulate, ultimately restricting intake due to the physical fill of the rumen (Magalhães et al., 2006).
Alkalinizing agents, such as quicklime, can be used to increase the digestion of the fibrous portion of sugarcane (Freitas, Rocha, Fagundes, Fonseca, \& Zonta, 2009) by partially solubilizing hemicellulose and expanding cellulose molecules. These processes culminate in the rupture of hydrogen bridge bonds, which increases the digestibility of these structural carbohydrates.

The addition of a nitrogen source, in turn, corrects the protein deficit encountered in sugarcanebased diets and promotes an increase in microbial production efficiency (Fernandes et al., 2009).

The present study proposes to examine the effects of sugarcane associated with a source of nonprotein nitrogen (a mixture of urea and ammonium sulfate) and an alkalizing agent (quicklime) on intake, rumen fermentation and kinetic parameters, nutrient digestibility, urinary nitrogen excretion and blood parameters of dairy steers. 


\section{Material and Methods}

\section{Animals and experimental model}

Four rumen-cannulated, castrated Jersey steers with an average body weight of $370 \pm 44.4 \mathrm{~kg}$ were used. The animals were adapted for 72 days, during which time they were fed sugarcane and concentrate at a 70:30 ratio (DM basis). The treatments were represented by fresh sugarcane $(\mathrm{Sc})$; fresh sugarcane with urea (ScUr); sugarcane hydrolyzed with quicklime (ScQ1); and sugarcane hydrolyzed with quicklime plus urea (ScUrQ1). The concentrate consisted of ground corn, soybean meal, urea and mineral salt (Table 1), and the diets contained similar levels of protein ( $12 \%$ crude protein [CP]) and energy (65\% total digestible nutrients [TDN]). Feed supply occurred at $08 \mathrm{~h} 00,11 \mathrm{~h} 00,14 \mathrm{~h} 00$ and $17 \mathrm{~h} 00$, in the proportions of $20,20,20$ and $40 \%$ (DM basis), respectively.

Table 1

Ingredients and nutritional contents of the experimental diets (DM basis), according to the respective treatments: fresh sugarcane (Sc), fresh sugarcane with urea (ScUr), sugarcane hydrolyzed with quicklime (ScQl) and sugarcane hydrolyzed with quicklime plus urea (ScUrQI)

\begin{tabular}{lcccc}
\hline Ingredient (\% in the diet) & Sc & ScUr & ScQ1 & ScUrQ1 \\
\hline Plain sugarcane & 70.00 & - & - & - \\
Sugarcane with urea & - & 70.00 & - & - \\
Sugarcane with quicklime & - & - & 70.00 & - \\
Sugarcane with urea plus quicklime & - & - & - & 70.00 \\
Corn grain & 13.20 & 25.48 & 13.20 & 25.48 \\
Soybean meal & 15.00 & 3.50 & 15.00 & 3.50 \\
Urea & 0.80 & 0.02 & 0.80 & 0.02 \\
Mineral salt ${ }^{1}$ & 1.00 & 1.00 & 1.00 & 1.00 \\
\hline Nutritional content (\% of diet) & & & & \\
Total digestible nutrients (TDN) & 65.24 & 66.24 & 65.24 & 66.24 \\
Crude protein (CP) & 12.04 & 12.04 & 12.04 & 12.04 \\
Rumen-degradable protein (RDP) & 38.90 & 40.09 & 38.90 & 40.09 \\
Neutral detergent fiber (NDF) & 35.76 & 35.98 & 35.76 & 35.98 \\
Acid detergent fiber (ADF) & 20.64 & 19.96 & 20.64 & 19.96 \\
Calcium (Ca) & 0.38 & 0.33 & 0.69 & 0.65 \\
Phosphorus (P) & 0.25 & 0.22 & 0.25 & 0.22 \\
\hline
\end{tabular}

${ }^{1}$ Calcium: 120 g; phosphorus: 88 g; sodium: 132g; sulfur: 12 g; cobalt: 55 mg; copper: 1.530 mg; iodine: 75 mg; manganese: 1,300 mg; selenium: $15 \mathrm{mg}$; zinc: $3,630 \mathrm{mg}$; chromium: $10 \mathrm{mg}$; fluorine: $880 \mathrm{mg}$; base phosphorylate: $100 \mathrm{~g}$.

The animals were distributed in a $4 \times 4$ Latin square design. The experimental periods lasted 18 days, of which the first seven were used for acclimation, followed by five days of evaluation of rumen degradability; one day for the measurements of $\mathrm{pH}$, ammonia, short-chain fatty acids (SCFA) and rumen kinetics; and five days for determining intake, total apparent digestibility, urinary nitrogen loss and serum glucose and urea levels.

For the Sc treatment, the freshly cut sugarcane was crushed to approximately $7 \mathrm{~mm}$ and immediately fed to the animals. In the ScUr 
treatment, the crushed sugarcane was treated with a mixture of urea and ammonium sulfate at the 9:1 ratio, respectively, in the amount of $1 \%$ (as-fed basis), and then immediately fed to the animals. For the ScQL treatment, the crushed sugarcane was treated with quicklime free of dioxins and furans, at a concentration of $1 \%$ (as-fed basis); this treatment was supplied $24 \mathrm{~h}$ after the addition of quicklime to the sugarcane. Lastly, in the ScUrQ1 treatment, the same procedure with quicklime was performed and, $24 \mathrm{~h}$ later, the urea-ammonium sulfate mixture was added at the time of supply to the animals; the product quantities were the same as described above. In the ScUr, ScQL and ScUrQ1 treatments, water was used to facilitate the homogenization of the additives with sugarcane, using the amount of 4 L for each $100 \mathrm{~kg}$ of fresh sugarcane. Subsequently, the products were mixed manually.

\section{Rumen degradability and kinetics}

Rumen degradability was evaluated from the 8th to the 12th day of each experimental period by decreasing sequential incubation and by the procedures described by Nocek (1988) and Agricultural and Food Research Council [AFRC] (1992). The feed incubation times followed the National Research Council [NRC] (2001) recommendations; however, to improve the adjustment curve, we chose to include an additional incubation time of $72 \mathrm{~h}$ or $96 \mathrm{~h}$ for the concentrate feeds and the roughage, respectively. The percentages of DM, CP, NDF and acid detergent fiber (ADF) that disappeared ruminally, at each incubation time, were determined according to $\mathrm{M}$. V. M. Oliveira et al. (2003), whereas potential and effective degradability was calculated using models described by Orskov and McDonald (1979) and McDonald (1981), respectively.

To determine the kinetics of liquid phase, on the 13th day, cobalt-EDTA complex diluted in distilled water was administered into the rumen of each animal before the first feeding, as suggested by
Udén, Colucci and Van Soest (1980). The rate of passage of the fluid and the ruminal concentration curves of cobalt-EDTA were adjusted to the singlecompartment exponential model described by Hungate (1966). Parameters of rumen fluid dynamics such as residence time in the rumen (h), volume (L), flow rate $\left(\mathrm{L} \mathrm{h}^{-1}\right)$ and turnover rate (number of times day $^{-1}$ ) were calculated as proposed by Maeng and Baldwin (1976) and Colucci et al. (1990).

For the analysis of rumen $\mathrm{pH}$, ammoniacal nitrogen $\left(\mathrm{N}^{-\mathrm{NH}_{3}}\right)$ and SCFA, 50-mL aliquots of rumen fluid were taken on the 13th day, with collections occurring at zero time (before the first meal) and then at 2-h intervals, up to eight hours after the first feeding. The $\mathrm{pH}$ was measured with a digital $\mathrm{pH}$ meter. The ammonia concentration in the rumen fluid was determined following the methodology described by Fenner (1965) and modified by Vieira (1980); and SCFA were determined according to F. P. Campos, Nussio and Nussio (2004).

During the 14th and 18th days of each experimental period, orts were collected from the troughs and weighed daily to determine daily intake. The feed supplied and the orts sampled daily were sampled in equitable portions.

\section{Digestibility}

To determine total nutrient digestibility, feces were harvested from the rectal ampulla on the 14th, 16 th and 18th days of each experimental period, two hours after the $08 \mathrm{~h} 00$ and $14 \mathrm{~h} 00$ feedings. After the end of each collection period, the samples were dried, ground and homogenized to form composite samples per animal, treatment and period. Fecal output was determined on the 12th and 13th days of each experimental period by collecting the animal feces in their entirety and weighing over $24 \mathrm{~h}$.

The DM, organic matter (OM), CP, ether extract (EE), NDF, ADF (previously treated with alphaamylase) and mineral matter (MM) contents were measured following the methodology described 
by Association of Official Agriculture Chemists [AOAC] (1990). Total carbohydrates (TC) and TDN levels were calculated using equations proposed by Sniffen, O'Connor, Van Soest, Fox and Russell (1992). Lastly, non-fibrous carbohydrates (NFC) were determined according to Hall (2000).

\section{Blood parameters and nitrogen excretion}

Spot urine samples were collected four hours after feeding, during spontaneous urination, on the 14th, 16th and 18th days of each experimental period. These were processed as proposed by Valadares, Broderick, Valadares and Clayton (1999) and then the concentrations of creatinine and urea were determined by kinetic and colorimetric methods, respectively. Urinary output was estimated according to Rennó (2003) and urinary urea losses

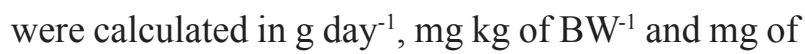

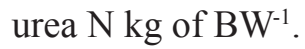

Blood was collected three hours after feeding on the 14th, 16th and 18th experimental days of each period (Valadares et al., 1999), using heparinized Vacutainer ${ }^{\circledR}$ tubes. Glucose and urea were then determined by colorimetry.

\section{Statistical analysis}

The evaluated parameters were subjected to tests to check the homogeneity of variances and to determine the normality of residuals. Afterwards, the data were subjected to analysis of variance and, when significant, means were compared by Tukey's test at 5\% significance, using R statistical software.

The statistical model used was $y_{i j k}=\mu+\alpha_{i}+\beta_{j}$ $+\tau_{k}+e_{i j k}$, where $y_{i j k}$ represents the observation of treatment $i$, in animal $j$ and period $k$; $\mu$ represents a general constant associated with this random variable; $\alpha_{i}$ is the effect of treatment $i(i=1,2,3$ and 4); $\beta_{j}$ is the effect of animal $j(j=1,2,3$ and 4$) ; \tau_{k}$ is the period effect; $(k=1,2,3$ and 4$)$; and $e_{i j k}$ is the experimental error associated with observation $y_{i j k}$.

\section{Results and Discussion}

The intakes of DM, expressed in $\mathrm{kg}$ /day, percentage of body weight $(\% \mathrm{BW})$ and metabolic weight $\left(\mathrm{g} / \mathrm{kgBW}^{0.75}\right)$; and of $\mathrm{OM}, \mathrm{CP}, \mathrm{NDF}, \mathrm{ADF}$, NFC, TC, EE and TDN were not influenced $(\mathrm{P}>0.05)$ by the treatments (Table 2). However, a higher MM intake was observed in the animals fed the diets with addition of quicklime (ScQ1 and ScUrQ1) as compared with those that received fresh sugarcane (Sc) and fresh sugarcane with urea (ScUr), which can be explained by the high calcium concentration in quicklime (Table 1).

The similar intakes of DM and fibrous components of sugarcane, especially NDF, indicate that the addition of $1 \%$ quicklime (as-fed basis) was possibly not effective in promoting hydrolysis of structural carbohydrates. This led to the separation of cellulose and hemicellulose, potentially degradable components, and lignin, an amorphous and indigestible compound. Therefore, there were no direct effects on intake.

In this experiment, the similar intake data observed between all treatments may be due to the lack of a protein deficit in control diet, since urea was added to the concentrate and the diets contained similar protein levels. This shows that despite being poor in nitrogenous compounds, sugarcane can be widely used as the only roughage in cattle diets as long as they are balanced and able to overcome the protein deficit, regardless of how this correction is made. 


\section{Table 2}

Means and respective coefficients of variation (CV) of daily intakes of DM (expressed in $\mathrm{kg}^{-1}$ day $^{-1}$, percentage of body weight $[\mathrm{BW}]$ and percentage of metabolic weight $\left[\% \mathrm{BW}^{0.75]}\right.$ ) and of OM, CP, NDF, ADF, HEM, NFC, TC, EE, MM and TDN by Jersey steers fed fresh sugarcane (Sc), fresh sugarcane with urea (ScUr), sugarcane hydrolyzed with quicklime (ScQl) and sugarcane hydrolyzed with quicklime plus urea (ScUrQI)

\begin{tabular}{|c|c|c|c|c|c|c|}
\hline \multirow{2}{*}{ Intake } & \multicolumn{4}{|c|}{ Treatment $^{1}$} & \multirow{2}{*}{ Mean } & \multirow{2}{*}{ CV $(\%)$} \\
\hline & $\mathrm{Sc}$ & $\mathrm{ScUr}$ & ScQl & ScUrQ1 & & \\
\hline DM $\left(\mathrm{kg} \mathrm{day}^{-1}\right)$ & 7.42 & 7.40 & 7.98 & 7.64 & 7.61 & 17.32 \\
\hline $\mathrm{DM}(\% \mathrm{BW})$ & 2.05 & 1.98 & 2.13 & 1.96 & 2.03 & 15.54 \\
\hline $\mathrm{DM}\left(\% \mathrm{BW}^{0.75}\right)$ & 89.36 & 87.03 & 93.55 & 85.57 & 88.88 & 15.98 \\
\hline $\mathrm{OM}\left(\mathrm{kg} \mathrm{day}^{-1}\right)$ & 7.15 & 7.18 & 7.44 & 7.16 & 7.23 & 17.40 \\
\hline $\mathrm{CP}\left(\mathrm{kg} \mathrm{day}^{-1}\right)$ & 0.79 & 0.86 & 0.85 & 0.87 & 0.84 & 17.18 \\
\hline NDF $\left(k g\right.$ day $\left.^{-1}\right)$ & 2.38 & 2.74 & 2.51 & 2.88 & 2.63 & 17.57 \\
\hline $\mathrm{ADF}\left(\mathrm{kg} \mathrm{day}{ }^{-1}\right)$ & 1.13 & 1.17 & 1.23 & 1.39 & 1.23 & 19.24 \\
\hline $\operatorname{HEM}\left(\mathrm{kg} \mathrm{day}^{-1}\right)$ & 1.25 & 1.57 & 1.28 & 1.49 & 1.40 & 18.40 \\
\hline NFC $\left(\mathrm{kg} \mathrm{day}^{-1}\right)$ & 3.87 & 3.43 & 3.94 & 3.27 & 3.63 & 17.78 \\
\hline TC $\left(\mathrm{kg} \mathrm{day}^{-1}\right)$ & 5.25 & 5.17 & 5.46 & 5.15 & 5.26 & 17.54 \\
\hline $\mathrm{EE}\left(\mathrm{kg} \mathrm{day}^{-1}\right)$ & 0.12 & 0.15 & 0.14 & 0.15 & 0.14 & 13.94 \\
\hline $\mathrm{MM}\left(\mathrm{kg} \mathrm{day}^{-1}\right)$ & $0.27 \mathrm{~b}$ & $0.22 \mathrm{~b}$ & $0.54 \mathrm{a}$ & $0.48 \mathrm{a}$ & 0.38 & 18.20 \\
\hline TDN $(\mathrm{kg} \text { day })^{1}$ & 5.32 & 5.30 & 5.65 & 5.43 & 5.43 & 19.90 \\
\hline
\end{tabular}

${ }^{1}$ Means followed by different letters in the same row differ $(\mathrm{P}<0.05)$ by Tukey's test.

The addition of urea and quicklime to sugarcane seems not to have elicited significant responses from rumen-fluid kinetics. Mean values for passage rate, ruminal volume, turnover time, flow rate and turnover rate are shown in Table 3.
In this experiment, the average ruminal volume of $72.70 \mathrm{~L}$ is equivalent to $19.64 \%$ of body weight, which is within the range of 15 to $21 \%$ deemed ideal according to Owens and Goetsch (1988). The average turnover time of $11 \mathrm{~h} 51 \mathrm{~min}$ found in the present study reflected in turnover rate, which averaged 2.02 times a day.

Table 3

Kinetics of the rumen fluid of Jersey steers fed fresh sugarcane (Sc), fresh sugarcane with urea (ScUr), sugarcane hydrolyzed with quicklime (ScQl) and sugarcane hydrolyzed with quicklime plus urea (ScUrQl)

\begin{tabular}{|c|c|c|c|c|c|c|}
\hline \multirow{2}{*}{ Item } & \multicolumn{4}{|c|}{ Treatment $^{1}$} & \multirow{2}{*}{ Mean } & \multirow{2}{*}{$\mathrm{CV}(\%)$} \\
\hline & $\mathrm{Sc}$ & ScUr & $\mathrm{ScQl}$ & ScUrQ1 & & \\
\hline Passage rate $\left(\% \mathrm{~h}^{-1}\right)$ & 9.23 & 7.52 & 8.42 & 10.60 & 8.94 & 24.12 \\
\hline Ruminal volume (L) & 65.10 & 72.77 & 84.84 & 68.10 & 72.70 & 21.52 \\
\hline Turnover time (h) & 11.15 & 14.17 & 12.09 & 9.99 & 11.85 & 24.07 \\
\hline Flow rate $\left(\mathrm{L} \mathrm{h}^{-1}\right)$ & 6.00 & 5.16 & 7.16 & 6.77 & 6.27 & 19.16 \\
\hline Turnover rate (time day ${ }^{-1}$ ) & 2.15 & 1.69 & 1.99 & 2.26 & 2.02 & 24.12 \\
\hline
\end{tabular}

${ }^{1}$ Rumen cobalt concentration data adjusted by diet model of (Colucci, Macleod, McMillan, \& Grovum, 1984). 
No significant differences were observed $(\mathrm{P}>0.05)$ between the evaluated treatments for ammoniacal nitrogen $\left(\mathrm{N}-\mathrm{NH}_{3}\right)$ concentrations or $\mathrm{pH}$ values (Table 4). The average $\mathrm{pH}$ value of 6.89 found in this study is inferred to be within the range considered favorable for the development of cellulolytic bacteria, which are responsible for the degradation of the fibrous fraction of the feed. According to Silva et al. (2007), a reduction in these values leads to a decrease in digestion, with deleterious effects on animal intake and performance.

Table 4

Means and coefficient of variation (CV) of $\mathrm{pH}$ values and ammoniacal nitrogen and short-chain fatty acid (SCFA) concentrations in the rumen fluid of Jersey steers fed fresh sugarcane (Sc), fresh sugarcane with urea (ScUr), sugarcane hydrolyzed with quicklime (ScQl) and sugarcane hydrolyzed with quicklime plus urea (ScUrQI)

\begin{tabular}{|c|c|c|c|c|c|c|}
\hline \multirow{2}{*}{ Parameter } & \multicolumn{4}{|c|}{ Treatment } & \multirow{2}{*}{ Mean } & \multirow{2}{*}{$\mathrm{CV}(\%)$} \\
\hline & $\mathrm{Sc}$ & $\mathrm{ScUr}$ & ScQ1 & ScUrQ1 & & \\
\hline $\mathrm{pH}$ & 6.84 & 6.82 & 6.96 & 6.94 & 6.89 & 1.62 \\
\hline $\mathrm{N}-\mathrm{NH}_{3} \mathrm{mg} 100 \mathrm{~mL}^{-1}$ & 8.30 & 9.05 & 8.38 & 9.78 & 8.88 & 26.43 \\
\hline \multirow{2}{*}{ Acetate } & $51.31 \mathrm{mM}$ & $54.76 \mathrm{mM}$ & $51.92 \mathrm{mM}$ & $51.31 \mathrm{mM}$ & $52.33 \mathrm{mM}$ & 17.33 \\
\hline & $63.09 \%$ & $62.47 \%$ & $58.96 \%$ & $63.09 \%$ & $61.90 \%$ & 8.43 \\
\hline \multirow{2}{*}{ Propionate } & $15.63 \mathrm{mM}$ & $15.65 \mathrm{mM}$ & $15.33 \mathrm{mM}$ & $15.63 \mathrm{mM}$ & $15.56 \mathrm{mM}$ & 29.49 \\
\hline & $19.22 \%$ & $17.70 \%$ & $21.28 \%$ & $19.22 \%$ & $19.36 \%$ & 15.50 \\
\hline \multirow{2}{*}{ Butyrate } & $14.21 \mathrm{mM}$ & $17.49 \mathrm{mM}$ & $16.14 \mathrm{mM}$ & $14.21 \mathrm{mM}$ & $15.51 \mathrm{mM}$ & 29.43 \\
\hline & $17.69 \%$ & $19.83 \%$ & $19.77 \%$ & $17.69 \%$ & $18.74 \%$ & 30.47 \\
\hline Acetate:propionate & 3.29 & 3.56 & 3.93 & 3.29 & 3.52 & 16.25 \\
\hline Total SCFA (mM) & 81.16 & 87.91 & 87.29 & 81.16 & 84.38 & 16.74 \\
\hline
\end{tabular}

The rumen $\mathrm{pH}$ value measured this study is close to the 6.87 reported by Carmo, Berchielli, Andrade and Zeola (2001), who tested sugarcanebased diets associated with urea. Silveira et al. (2009) obtained average rumen $\mathrm{pH}$ values of 6.87 and 6.58 using sugarcane and sugarcane treated with urea, respectively. Missio et al. (2012) studied the addition of quicklime to sugarcane and obtained mean rumen $\mathrm{pH}$ values of 6.80 and 6.70 using fresh and hydrolyzed sugarcane, respectively.

The $\mathrm{N}-\mathrm{NH}_{3}$ concentrations in the rumen fluid ranged between 8.38 and $9.78 \mathrm{mg} 100 \mathrm{~mL}^{-1}$, which are higher values than the 2.0 to $5.0 \mathrm{mg} 100 \mathrm{~mL}^{-1}$ considered sufficient to promote the growth of rumen microbiota as suggested by Slyter, Satter and Dinius (1979).
Ortiz-Rubio, Orskov, Milne and Galina (2007) added urea with a non-protein nitrogen source to sugarcane diets and observed an increase in the rumen concentration of $\mathrm{NH}_{3}$ and an increase in sugarcane intake. The authors described optimal responses for rumen degradation rate achieved when the $\mathrm{N}-\mathrm{NH}_{3}$ concentration was between 9.0 and $11.0 \mathrm{mg} 100 \mathrm{~mL}^{-1}$.

The balance between production, absorption and use of $\mathrm{N}^{-\mathrm{NH}_{3}}$ by microorganisms is known to be responsible for the rumen ammonia concentrations. Thus, bacteria use $\mathrm{N}_{-} \mathrm{NH}_{3}$ as a source of nitrogen for the synthesis of microbial protein. However, protein degradation in the rumen can produce $\mathrm{N}-\mathrm{NH}_{3}$ in amounts that exceed the utilization capacity of microorganisms (Preston, 1986). Consequently, the 
excess $\mathrm{N}-\mathrm{NH}_{3}$ is absorbed by the epithelium, and this is followed by metabolization and synthesis of urea by the liver and then by salivary turnover or loss of this nitrogen through urinary excretion.

Total SCFA concentration was not affected by the treatments $(\mathrm{P}>0.05)$, and neither were the concentrations of acetate, propionate and butyrate or acetate:propionate ratio (Table 4). The acetate:propionate:butyrate ratio in this study was $62: 20: 18$, which is close to the $65: 25: 10$ considered normal for roughage-based diets (Nussio, Campos, \& Lima, 2006).

Table 5 shows the coefficients of degradability fractions "a", "b" and "c" of the DM and their respective effective degradabilities. The potential degradability ("a" + " "b" fractions) values of sugarcane averaged 52.58\%. Silveira et al. (2009) did not observe the influence of the addition of urea on sugarcane degradability, which averaged $55.40 \%$, a value similar to that described in the current experiment. In contrast, Ortiz-Rubio et al. (2007) obtained an average potential degradability of $58.25 \%$ and reported the effect of adding urea as a protein source for sugarcane. Macedo et al. (2011) obtained an increase in the potential degradability of sugarcane after adding quicklime, describing the values of $63.4 \%$ and $72.7 \%$ for plain sugarcane and sugarcane plus lime, respectively.

\section{Table 5}

Values of "'a", "b" and "c" coefficients, referring to rumen degradability of dry matter, and their effective degradabilities for passage rates of 2,5 and $8 \%$ per hour

\begin{tabular}{lcccccc}
\hline Feedstuff & "a"1 & "b"1 & "c"1 & $2 \% / \mathrm{h}$ & $5 \% / \mathrm{h}$ & $8 \% / \mathrm{h}$ \\
\hline Soybean meal & 22.71 & 59.69 & 0.083 & 70.8 & 60.0 & 53.2 \\
Corn & 28.55 & 56.24 & 0.058 & 70.3 & 58.7 & 52.1 \\
\hline Sugarcane & 36.17 & 17.20 & 0.040 & 52.6 & 51.5 & 50.5 \\
ScUr & 36.15 & 12.55 & 0.014 & 47.1 & 45.4 & 44.1 \\
ScQ1 & 30.13 & 23.71 & 0.039 & 52.7 & 51.1 & 49.8 \\
ScUrQ1 & 36.62 & 17.81 & 0.016 & 52.4 & 50.2 & 48.5 \\
\hline
\end{tabular}

1 "a": soluble fraction degraded at zero time; "b": potential degradability as a function of time; "c": fractional rate of degradation of fraction "b" per unit of time.

The effective degradability values of sugarcane found in this experiment did not differ. M. M. Campos, Borges, Lopes, Pancoti and Reis e Silva (2011) also found no differences in the effective degradability of sugarcane following the addition of lime. Silveira et al. (2009) obtained effective degradability coefficients of $45.77 \%$ for plain sugarcane and $47.19 \%$ for urea-treated sugarcane, at a rate of $2 \% \mathrm{~h}^{-1}$, which are inferior results in relation to the current findings.

Plasma glucose levels were not influenced by the treatment of sugarcane with urea and quicklime, averaging $55.47 \mathrm{mg} \mathrm{dL}^{-1}$ (Table 6). The glucose levels observed in this study are in line with values considered normal for cattle, which can vary from 45.00 to $75.00 \mathrm{mg} \mathrm{dL}^{-1}$ (Kaneko, Harvey, \& Bruss, 1997). Serum urea levels were influenced $(P<0.05)$ by the treatments, with higher mean values observed in the animals fed ScUr and ScUrQ1 than in those fed $\mathrm{Sc}$ and $\mathrm{ScQ} 1$. This finding indicates high availability of nitrogen in the rumen with consequent papillary absorption and transformation of this ammonia into urea in the liver tissue (Table 6).

Although serum urea levels varied between the treatments, the observed values are considered normal for adult cattle, which exhibit serum urea 
concentrations of up to $27.4 \mathrm{mg} \mathrm{dL}^{-1}$ (Jenkins, Green, \& Clark, 1982). However, these values are below the limit $\left(34.28 \mathrm{mg} \mathrm{dL}^{-1}\right)$ proposed by Valadares, Gonçalves, Rodriguez, Valadares and Sampaio
(1997) for maximum microbial efficiency. Urinary nitrogen and urea excretions were similar between the treatment groups; therefore, there was no protein or nitrogen loss between the diets (Table 6).

Table 6

Plasma levels of glucose and urea; and loss of urea and urinary nitrogen with their respective coefficients of variation (CV), in steers fed fresh sugarcane (Sc), fresh sugarcane with urea (ScUr), sugarcane hydrolyzed with quicklime (ScQl) and sugarcane hydrolyzed with quicklime plus urea (ScUrQI)

\begin{tabular}{|c|c|c|c|c|c|c|}
\hline \multirow{2}{*}{ Parameter } & \multicolumn{4}{|c|}{ Treatment $^{1}$} & \multirow{2}{*}{ Mean } & \multirow{2}{*}{$\mathrm{CV}(\%)$} \\
\hline & $\mathrm{Sc}$ & ScUr & ScQ1 & ScUrQ1 & & \\
\hline Glucose $\left(\mathrm{mg} \mathrm{dL}^{-1}\right)$ & 55.7 & 54.4 & 54.6 & 57.2 & 55.4 & 8.63 \\
\hline Urea $\left(\mathrm{mg} \mathrm{dL}^{-1}\right)$ & $12.3 \mathrm{~b}$ & $20.4 \mathrm{a}$ & $15.3 \mathrm{~b}$ & $21.1 \mathrm{a}$ & 17.3 & 18.98 \\
\hline Urea loss $\left(\mathrm{g} \mathrm{day}^{-1}\right)$ & 90.5 & 166.6 & 123.3 & 156.1 & 134.1 & 27.11 \\
\hline Urea loss (mg kg BW$\left.{ }^{-1}\right)$ & 233.6 & 444.2 & 313.9 & 415.5 & 351.8 & 28.25 \\
\hline $\mathrm{N}$ loss $\left(\mathrm{mg} \mathrm{kg} \mathrm{BW}{ }^{-1}\right)$ & 108.8 & 207.0 & 146.3 & 193.6 & 163.9 & 28.25 \\
\hline
\end{tabular}

${ }^{1}$ Means followed by different letters in the same row are different $(\mathrm{P}<0.05)$ by Tukey's test.

Similar digestibility coefficients of DM, OM, $\mathrm{CP}, \mathrm{NDF}, \mathrm{ADF}, \mathrm{NFC}$ and EE were detected $(\mathrm{p}>0.05)$ between the treatment groups (Table 7), which proves the ineffectiveness of sugarcane hydrolysis on the digestive parameters (Missio et al., 2012). Likewise, the addition of a non-protein nitrogen does not influence the digestibility of sugarcane (Pereira et al., 2008).

Table 7

Apparent digestibility coefficients in steers fed fresh sugarcane (Sc), fresh sugarcane with urea (ScUr), sugarcane hydrolyzed with quicklime (ScQl) and sugarcane hydrolyzed with quicklime plus urea (ScUrQI)

\begin{tabular}{|c|c|c|c|c|c|c|}
\hline \multirow{2}{*}{ Digestibility $^{1}$} & \multicolumn{4}{|c|}{ Treatment } & \multirow{2}{*}{ Mean } & \multirow{2}{*}{$\mathrm{CV}(\%)$} \\
\hline & $\mathrm{Sc}$ & ScUr & ScQ1 & ScUrQ1 & & \\
\hline $\mathrm{DM}$ & 70.33 & 68.25 & 71.21 & 71.02 & 70.20 & 6.62 \\
\hline $\mathrm{OM}$ & 73.42 & 71.22 & 74.03 & 74.55 & 73.30 & 5.62 \\
\hline $\mathrm{CP}$ & 63.85 & 63.85 & 64.74 & 70.34 & 65.70 & 8.34 \\
\hline NDF & 43.67 & 46.30 & 47.41 & 56.10 & 48.40 & 19.14 \\
\hline $\mathrm{ADF}$ & 32.94 & 34.14 & 39.77 & 48.72 & 38.90 & 35.16 \\
\hline HEM & 52.99 & 56.61 & 54.75 & 59.67 & 56.00 & 17.16 \\
\hline NFC & 92.78 & 92.63 & 93.20 & 93.82 & 93.10 & 3.15 \\
\hline $\mathrm{TC}$ & 74.32 & 72.20 & 75.36 & 74.67 & 74.15 & 5.26 \\
\hline $\mathrm{EE}$ & 65.31 & 70.03 & 69.36 & 65.28 & 67.50 & 12.95 \\
\hline MM & $18.67 \mathrm{~b}$ & $21.35 \mathrm{ab}$ & $25.85 \mathrm{a}$ & $26.46 \mathrm{a}$ & 23.08 & 11.78 \\
\hline
\end{tabular}

${ }^{1}$ Digestibility percentage of dry matter (DM), organic matter (OM), crude protein (CP), neutral detergent fiber (NDF), acid detergent fiber (ADF), hemicellulose (HEM), non-fibrous carbohydrates (NFC), total carbohydrates (TC), ether extract (DEE) and mineral matter (MM). 
Mota et al. (2010) described an improvement in the digestibility of DM and NDF of sugarcane with the use of quicklime and hydrated lime. M. D. S. Oliveira et al. (2007) also observed an increase in the in vitro digestibility of DM, NDF and ADF from sugarcane following the addition of 0.5 and $1.0 \%$ quicklime (as-fed basis). M. D. S. Oliveira et al. (2012) compared the digestibility of different varieties of sugarcane, hydrolyzed with $1 \%$ quicklime or non-hydrolyzed, and, likewise, observed increased digestibility for NDF and ADF, but similar results for DM.

\section{Conclusion}

The addition of urea to sugarcane or its addition associated with hydrolysis with quicklime does not affect rumen kinetics or rumen parameters. The evaluated urea inclusion level promotes an increase in serum urea levels but does not influence the urinary excretions of nitrogen or urea. The addition of $1.0 \%$ quicklime (as-fed basis) does not promote changes in rumen-fluid kinetics or satisfactory effects on the digestive parameters of the fibrous fraction of sugarcane.

\section{References}

Agricultural and Food Research Council (Great Britain). Technical Committee on Responses to Nutrients (1992). Nutritive requirements of ruminant animals: protein. Oxon, C.A.B International.

Association of Official Agriculture Chemists (1990). Official methods of analysis of the association of the $A O A C$. Washington: AOAC International.

Campos, F. P., Nussio, C. M. B., \& Nussio, L. G. (2004). Métodos de análises de alimentos. Piracicaba: Editora FEALQ.

Campos, M. M., Borges, A. L. C. C., Lopes, F. C. F., Pancoti, C. G., \& Reis e Silva, R. (2011). Degradabilidade in situ da cana-de-açúcar tratada ou não com óxido de cálcio, em novilhas leiteiras Holandês x Gir. Arquivo Brasileiro de Medicina Veterinária e Zootecnia, 63(6), 1487-1492. doi: 10. 1590/S0102-09352011000600028
Carmo, C. A., Berchielli, T. T., Andrade, P., \& Zeola, N. M. B. L. (2001). Degradabilidade da matéria seca e fibra em detergente neutro da cana-de-açúcar (Saccharum spp) com diferentes fontes de proteína. Revista Brasileira de Zootecnia, 30(6), 2126-2133. doi: 10.1590/S1516-35982001000800023

Colucci, P. E., Macleod, G. K., McMillan, I., \& Grovum, W. L. (1984). Comparative digestion and digest kinetics in sheep and cattle. Canadian Journal of Animal Science, 64(5), 173-174. doi: 10.4141/ cjas $84-210$

Colucci, P. E., Macleod, G. K., Grovum, W. L., I. McMillan, I., \& Barney, D. J. (1990). Digesta kinetics in sheep and cattle fed diets with different forage to concentrate ratios at high and low intakes. Journal Dairy Science, 73(8), 2143-2156. doi: 10.3168/jds. S0022-0302(90)78895-9

Fenner, H. (1965). Method for determining total volatile bases in rumen fluid by steam distillation. Journal of Dairy Science, 48(4), 249-251. doi: 10.3168/jds. S0022-0302(65)88206-6

Fernandes, J. J. R., Pires, A. V., Oliveira, R. C., Jr., Santos, F. A. P., Susan, I., \& Carvalho, E. R. (2009). Farelo de soja em substituição à ureia em dietas para bovinos de corte em crescimento. Ciência Animal Brasileira, 10(2), 373-378. Recuperado de https:// www.revistas.ufg.br/vet/article/view/6583

Freitas, A. W. P., Rocha, F. C., Fagundes, J. L., Fonseca, R., \& Zonta, A. (2009). Avaliação da cana-de-açúcar com diferentes níveis de hidróxido de cálcio. Boletim de Indústria Animal, 66(2), 137-144. Recuperado de http://www.iz.sp.gov.br/bia/index.php/bia/article/ view/1093

Hall, M. B. (2000). Neutral detergent-soluble carbohydrates. Nutritional relevance and analysis. A Laboratory Manual. (Bulletin n. 339). Gainesville: University of Florida. Retrieved from http:// dairy.ifas.ufl.edu/other/files/Manual___Neutral Detergent-Soluble_Carbohydrates_Nutritional_ Relevance_and_Analysis.pdf

Hungate, R. E. (1966). The Rumen and its microbes. New York: Academic Press.

Jenkins, S. J., Green, S. A., \& Clark, P. A. (1982). Clinical chemistry reference values of normal domestic animals in various age groups-as Determined on the ABA-100. Cornell Veterinarian, 72(4), 403415. Recuperado de https://europepmc.org/article/ $\operatorname{med} / 7140302$

Kaneko, J. J., Harvey, J. W., \& Bruss, M. L. (1997). Clinical biochemistry of domestic animals (5nd ed.). San Diego: Academic Press. 
Macedo, T. M., Pires, A. J. V., Carvalho, G. G. P., Lopes, W. B., Soares, C. O., \& Chagas, D. M. T. (2011). Degradabilidade da matéria seca e da fração fibrosa da cana-de-açúcar tratada com óxido de cálcio. Revista Brasileira de Saúde Produção Animal, 12(2), 429440. Recuperado de http://revistas.ufba.br/ index. $\mathrm{php} / \mathrm{rbspa} /$ article/view/1983/1112

Maeng, W. J., \& Baldwin, R. L. (1976). Dynamics of fermentation of purified diet and microbial growth in the rumen. Journal of Dairy Science, 59(4), 636-642. doi: 10.3168/jds.S0022-0302(76)84252-X

Magalhães, A. L. R., Campos, J. M. S., Cabral, L. S., Mello, R., Freitas, J. A., Torres, R. A.,... Assis, A. J. (2006). Cana-de-açúcar em substituição à silagem de milho em dietas para vacas em lactação: parâmetros digestivos e ruminais. Revista Brasileira de Zootecnia, 35(2), 591-599. doi: 10.1590/S151635982006000200036

McDonald, I. (1981). Short note: a revised model for the estimation of protein degradability in the rumen. Journal of Agricultural Science, 96(1), 251-252. doi: 10.1017/S0021859600032081

Missio, R. L., Oliveira, M. D. S., Sforcini, M. P. R., Rennó, F. P., Freitas, J. E., Jr., Elejade, D. A. G.,... Abud, G. C. (2012). Digestion of feed fractions and intake of heifers fed hydrolyzed sugarcane stored for different periods. Revista Brasileira de Zootecnia, 41(7), 1737-1746. doi: 10.1590/S1516-35982012 000700025

Mota, D. A., Oliveira, M. D. S., Domingues, F. N., Manzi, G. M., Ferreira, D. S., \& Santos, J. (2010). Hidrólise da cana-de-açúcar com cal virgem ou cal hidratada. Revista Brasileira de Zootecnia, 39(6), 1186-1190. doi: 10.1590/S1516-35982010000600004

National Research Council (2001). Nutrient requirements of dairy cattle (7nd ed.). Washington: National Academy Press.

Nocek, J. E. (1988). In situ and other methods to estimate ruminal protein and energy digestibility: a review. Journal of Dairy Science, 71(5), 2051-2069. doi: 10.3168/jds.S0022-0302(88)79781-7

Nussio, L. G., Campos, F. P., \& Lima, M. L. M. (2006). Metabolismo de carboidratos estruturais. In $\mathrm{T}$. T. Berchielli, A. V. Pires, \& S. G. Oliveira (Eds.), Nutrição de ruminantes (pp. 183-228). Jaboticabal, SP: Editora FUNEP.

Oliveira, M. D. S., Andrade, A. T., Barbosa, J. C., Silva, T. M., Fernandes, A. R. M., Caldeirão, E., \& Carabolante, A. (2007). Digestibilidade da cana-deaçúcar hidrolisada, in natura e ensilada para bovinos.
Ciência Animal Brasileira, 8(1), 41-50. Recuperado de https://www.revistas.ufg.br/vet/article/ view/1157

Oliveira, M. D. S., Rêgo, A. C., Sforcini, M. P. R., Freitas, J. E., Jr., Santos, J., \& Carvalho, M. V. (2012). Bromatological characteristics and in vitro digestibility of four sugarcane varieties subjected or not to the application of quicklime. Acta Scientiarum. Animal Sciences, 34(4), 355-361. doi: 10.4025/ actascianimsci.v34i4.13775

Oliveira, M. V. M., Vargas, F. M., Jr., Sanchez, L. M. B., Paris, W., Frizzo, A., Haygert, I. P.,... Cerdótes, L. (2003). Degradabilidade ruminal e digestibilidade intestinal de alimentos por intermédio da técnica in situ associada à do saco de náilon móvel. Revista Brasileira de Zootecnia, 32(6, Suppl. 2), 2023-2031. doi: 10.1590/S1516-35982003000800028

Orskov, E. R., \& McDonald, I. (1979). The estimation of protein degradability in the rumen from incubation measurements weighted according to rate of passage. Journal of Agricultural Science, 92(2), 499-503. doi: $10.1017 / \mathrm{S} 0021859600063048$

Ortiz-Rubio, M. A., Orskov, E. R., Milne, J., \& Galina, H. M. A. (2007). Effect of different sources of nitrogen on in situ degradability and feed intake of Zebu cattle fed sugarcane tops (Saccharum officinarum). Animal Feed Science and Technology, 139(3-4), 143-158. doi: 10.1016/j.anifeedsci.2007. 01.016

Owens, F. N., \& Goetsch, A. L. (1988). Ruminal fermentation. In D. C. Church (Ed.), The ruminant animal digestive physiology and nutrition (pp. 146171). Englewood Cliffs: O \& Books Inc.

Pereira, O. G., Souza, V. G., Valadares, S. C., Fo., Pereira, D. H., Ribeiro, K. G., \& Cecon, P. R. (2008). Consumo e digestibilidade dos nutrientes e desempenho de bovinos de corte recebendo dietas com diferentes níveis de ureia. Ciência Animal Brasileira, 9(3), 552562. Recuperado de https://www.revistas.ufg.br/vet/ article/view/ 643

Preston, T. R. (1986). Analytical methods for characterizing feed resources for ruminants. In T. R. Preston (Org.), Better utilization of crop residues and by-products in animal feeding: research guidelines. 2. A practical manual for research workers (Chap 6, pp. 106). Rome, Italy: FAO.

Rennó, L. N. (2003). Consumo, digestibilidade total e parcial, produção microbiana, parâmetros ruminais e excreções de ureia e creatinina em novilhos alimentados com dietas contendo quatro níveis de ureia ou dois níveis de proteína. Tese de doutorado em zootecnia, Universidade Federal de Viçosa, Viçosa, MG, Brasil. 
Silva, E. A., Berchielli, T. T., Reis, R. A., Pires, A. V., Sato, K. J., Paes, J. M. V., \& Lopes, A. D. (2007). Teores de proteína bruta para bovinos alimentados com feno de capim-tifton 85: parâmetros ruminais, eficiência de síntese microbiana e degradabilidade in situ. Revista Brasileira de Zootecnia, 36(1), 225237. doi: 10.1590/S1516-35982007000100027

Silveira, R. N., Berchielli, T. T., Canesin, R. C., Messana, J. D., Fernandes, J. J. R. F., \& Pires, A. V. (2009) Influência do nitrogênio degradável no rúmen sobre degradabilidade in situ, os parâmetros ruminais e a eficiência da síntese de proteína microbiana em novilhos alimentados com cana-de-açúcar. Revista Brasileira de Zootecnia, 38(3), 570-579. doi: 10.1590/S1516-35982009000300024

Slyter, L. L., Satter, L. D., \& Dinius, D. A. (1979). Effect of ruminal ammonia concentration on nitrogen utilization by steers. Journal of Animal Science, 48(4), 906-912. doi: 10.2527/jas1979.484906x

Sniffen, C. J., O‘Connor, J. D., Van Soest, P. J., Fox, D. G., \& Russell, J. B. (1992). A net carbohydrate and protein systen for evaluating cattle diets; II. Carbohydrate and protein availabiliy. Journal of Animal Science, 70(11), 3562-3577. doi: $10.2527 / 1992.70113562 \mathrm{x}$
Udén, P., Colucci, P. E., \& Van Soest, P. J. (1980). Investigation of chromium, cerium and cobalt as markers in digesta. Rate of passage studies. Journal Science Food Agriculture, 31(7), 625-632. doi: $10.1002 /$ jsfa. 2740310702

Valadares, R. F. D., Broderick, G. A., Valadares, S. C., F., \& Clayton, M. K. (1999). Effect of replacing alfalfa silage with high moisture corn on ruminal protein synthesis estimated from excretion of total purine derivates. Journal of Dairy Science, 82(12), 26862696. doi: 10.3168/jds.S0022-0302(99)75525-6

Valadares, R. F. D., Gonçalves, L. C., Rodriguez, N. M., Valadares, S. C., Fº., \& Sampaio, I. B. (1997). Níveis de proteína em dietas de bovinos. 4. Concentrações de amônia ruminal e ureia plasmática e excreções de úreia e creatinina. Revista Brasileira de Zootecnia, 26(6), 1270-1278. Recuperado de http://www.scielo. br/scielo.php?script $=$ sci_nlinks\&ref $=000145 \&$ pid $=$ S1516-3598200000040003800037\& lng=en

Vieira, P. F. (1980). Efeito do formaldeído na proteção de proteinas e lipídios em rações para ruminantes. Tese de doutorado, Universidade Federal de Viçosa, Viçosa, MG, Brasil. 